\title{
Peningkatan Literasi Keuangan di Kampung Makan Rafel's Jakarta Barat
}

\author{
Ekayana Sangkasari Paranita $^{1 *}$, Azami Syukron Harahap ${ }^{2}$ iD \\ ${ }^{12}$ Fakultas Ekonomi dan Bisnis, Universitas Sahid, Jakarta Selatan, Indonesia \\ *Corresponding author: ekayanasparanita@usahid.ac.id
}

\begin{abstract}
Abstrack
Kampung Makan Rafel's merupakan Pujasera kecil di Jakarta Barat yang tenant dan pengelolanya mengalami kesulitan operasional karena rendahnya perputaran kas. Para tenant dan pengelola belum kenal sumber pembiayaan terpercaya, belum paham pengelolaan keuangan, dan belum paham investasi. Rendahnya tingkat literasi keuangan sangat memprihatinkan karena beresiko buruk terhadap kelangsungan usaha. Program pengabdian kepada masyarakat ini bertujuan meningkatkan literasi keuangan para tenant dan pengelola Kampung Makan Rafel's. Metode dalam edukasi literasi keuangan meliputi persiapan, pendampingan literasi keuangan, serta monitoring dan evaluasi. Program pendampingan literasi keuangan menghasilkan kemajuan positif terbukti dari peserta paham produk dan jasa keuangan, muncul kesadaran menabung, terampil mengisi buku kas sebagai sarana perencanaan keuangan, dan paham instrumen investasi yang aman. Hal ini berimplikasi bahwa para tenant dan pengelola Kampung Makan Rafel's sebaiknya tetap dipantau literasi keuangannya, sehingga dapat mempertahankan usahanya secara berkesinambungan.
\end{abstract}

Keywords: Literasi Keuangan, Pemahaman Jasa Keuangan, Pengelolaan Keuangan

\section{Abstrack}

Kampung Makan Rafel's is a small food court in West Jakarta whose tenants and managers experience operational difficulties due to low cash flow. Tenants and managers do not know a reliable source of financing, do not understand financial management, and do not understand investment. The low level of financial literacy is very concerning because it has a bad risk to business continuity. This community service program aims to improve the financial literacy of tenants and managers of Kampung Makan Rafel's. Methods in financial literacy education include preparation, financial literacy assistance, and monitoring and evaluation. The financial literacy mentoring program has resulted in proven positive progress from participants who understand financial products and services, raise awareness of saving, have skills in filling out cash books as a means of financial planning, and understand safe investment instruments. This implies that the tenants and managers of Kampung Makan Rafel's financial literacy should be monitored, so that they can sustain their business in a sustainable manner.

Keywords: Financial Literacy, Understanding Of Financial Services, Financial Management.

\section{Introduction}

Jakarta Barat merupakan salah satu wilayah pusat industri di Propinsi Daerah Khusus Ibukota Jakarta, ditandai dengan banyaknya pabrik pengolahan industri ringan, tekstil, dan bahan kimia. Selain itu Jakarta Barat juga menjadi rumah sejumlah kampus perguruan tinggi swasta. Namun pesatnya pertumbuhan Jakarta Barat belum diikuti dengan pesatnya angka serapan tenaga kerja di sektor formal. Hingga tahun 2019, terdapat lebih dari 64 persen angkatan kerja di Jakarta Barat bekerja di sektor informal dan masih terdapat pengangguran terbuka sebanyak 6 persen atau 60.100 orang (Badan Pusat Statistik, 2020). Salah satu usaha yang bisa dilakukan adalah membuat usaha mikro kecil dan menengah (UMKM). Usaha Mikro Kecil dan Menengah (UMKM) telah terbukti berperan signifikan dalam pertumbuhan ekonomi di Indonesia dan paling mampu bertahan dalam kondisi krisis sekalipun. Sektor ini

$\begin{array}{lll}\text { History: } & & \text { Publisher: Undiksha Press } \\ \text { Received } & \text { : 23 June } 2020 & \text { Licensed: This work is licensed under } \\ \text { Revised } & \text { : 23 July } 2020 & \text { a Creative Commons Attribution 3.0 License } \\ \text { Accepted } & \text { : } 30 \text { July } 2020 & \text { CC (D) OP } \\ \text { Published } & \text { : } 01 \text { August } 2020 & \end{array}$


berkontribusi signifikan dalam pengembangan ekonomi kerakyatan dan penciptaan lapangan kerja (Aribawa, 2016; Sabilla \& Wijayangka, 2019; Amalia \& Rahmawati, 2019). Salah satu usaha mikro kecil dan menengah (UMKM) mendirikan Pusat Jajanan Serba Ada (Pujasera).

Kampung Makan Rafel's merupakan salah satu Pujasera di kawasan Jakarta Barat. Kuliner yang ditawarkan cukup beragam, harga yang dipatok dalam kisaran wajar, namun pengunjung yang datang masih sangat terbatas. Jalan raya di depan lokasi cukup ramai menjadi jalur lalu lintas ke sejumlah ruang publik, tetapi belum menjadi pemicu ramainya pengunjung. Hal ini menyebabkan tenant mengalami kesulitan operasional karena rendahnya perputaran kas. Permasalahan yang dihadapi tenant Kampung Makan Rafel's terkait perputaran kas dapat mengakibatkan hilangnya kesempatan untuk meningkatkan kuantitas dan kualitas produksinya (Amalia \& Rahmawati, 2019; Purwidianti \& Tubastuvi, 2019). Desakan kondisi ekonomi menyebabkan beberapa tenant mulai gelisah untuk mencari alternatif pendapatan lain dan mencari pinjaman untuk memenuhi kebutuhannya. Para tenant belum mengenali sumber pembiayaan yang terpercaya, belum memahami pengelolaan keuangan, dan belum memahami alokasi investasi dari hasil penjualannya.

Rendahnya tingkat literasi keuangan para tenant Kampung Makan Rafel's tersebut menjadi fenomena yang sangat memprihatinkan. Hal ini sejalan dengan kondisi pada mayoritas pelaku usaha mikro bahwa mereka cenderung belum layak dan belum memadai untuk mengakses jasa dan layanan keuangan (Anggraeni, 2016; Hafifah, 2019; Jumhur, 2015; Puspitaningtyas, 2017; Sudana et al., 2017; Suryani \& Ramadhan, 2017).

Program pengabdian kepada masyarakat yang melakukan pendampingan pada UMKM di Jawa Timur menyimpulkan bahwa rendahnya literasi keuangan dapat beresiko terlilit rentenir (Amalia \& Rahmawati, 2019). Kajian pada UMKM di Jawa Barat menyatakan literasi keuangan berpengaruh signifikan terhadap pertumbuhan usaha (Sabilla \& Wijayangka, 2019). Penelitian pada UMKM di Makassar menyimpulkan bahwa literasi keuangan menjadi determinan keputusan pembiayaan (Nohong et al., 2019). Analisis literasi keuangan pada UMKM di Medan menyatakan bahwa literasi keuangan mutlak diperlukan demi kelangsungan usaha dan bertahan dalam iklim kompetisi (Panggabean et al., 2018). Studi pada UMKM di Jawa Timur menyatakan bahwa literasi keuangan merupakan faktor signifikan yang berperan dalam kinerja UMKM (Pramestiningrum \& Iramani, 2020; Rahayu \& Musdholifah, 2017). Bahkan sejumlah riset di negara berkembang juga menyatakan bahwa literasi keuangan berkontribusi nyata dalam kesinambungan bisnis dan kinerja UMKM (Agyapong \& Attram, 2019; Eniola \& Entebang, 2015; Mabula \& Ping, 2018; Mashizha et al., 2019; Masiyamoorthy et al., 2017; Ripain et al., 2017; Ye \& Kulathunga, 2019).

Kondisi rendahnya tingkat literasi keuangan di kalangan tenant Kampung Makan Rafel's dimanfaatkan segelintir pihak yang menawarkan jalan pintas pembiayaan dengan biaya tinggi dan investasi menggiurkan. Jika tidak segera diambil langkah nyata, dikhawatirkan tenant Kampung Makan Rafel's akan terlilit pembiayaan yang mencekik leher, mismanajemen dalam mengelola keuangannya, dan tergiur investasi tak bertanggung jawab. Oleh karena itu mendesak untuk melaksanakan program pengabdian masyarakat untuk meningkatkan literasi keuangan bagi tenant Kampung Makan Rafel's.

Literasi keuangan merupakan kemampuan seseorang untuk memperoleh informasi, menganalisis, mengelola dan berkomunikasi tentang situasi keuangan pribadi (Mukhibat, 2020; Nadya \& Karina, 2017) . Literasi keuangan dari sudut pandang individu berdampak pada pengelolaan keuangan, kemampuan untuk memiliki tabungan, pemenuhan kebutuhan pendidikan, dan dana hari tua. Pengelolaan uang yang tidak efektif akan berdampak pada krisis keuangan keluarga (Amalia \& Rahmawati, 2019; Sudana et al., 2017; Suryani \& Ramadhan, 2017; Tedjowidjojo, 2016). Konsep tersebut dapat diadaptasi bagi tenant Kampung Makan Rafel's untuk meraih tujuan usahanya, memiliki orientasi pengembangan usaha, dan mampu eksis dalam kondisi ekonomi yang menantang. 
Kampung Makan Rafel's membuka layanan di sekitar pemukiman penduduk di Kelurahan Meruya Utara, Kecamatan Kembangan, Jakarta Barat. Strategi pemilihan lokasi tersebut didasari pemikiran bahwa banyak warga yang juga membutuhkan preferensi kuliner yang beragam, namun tidak memiliki waktu dan pendanaan yang memadai untuk menikmati Pujasera di supermarket dan mall. Lokasi Kampung Makan Rafel's adalah sebagaimana Gambar 1.

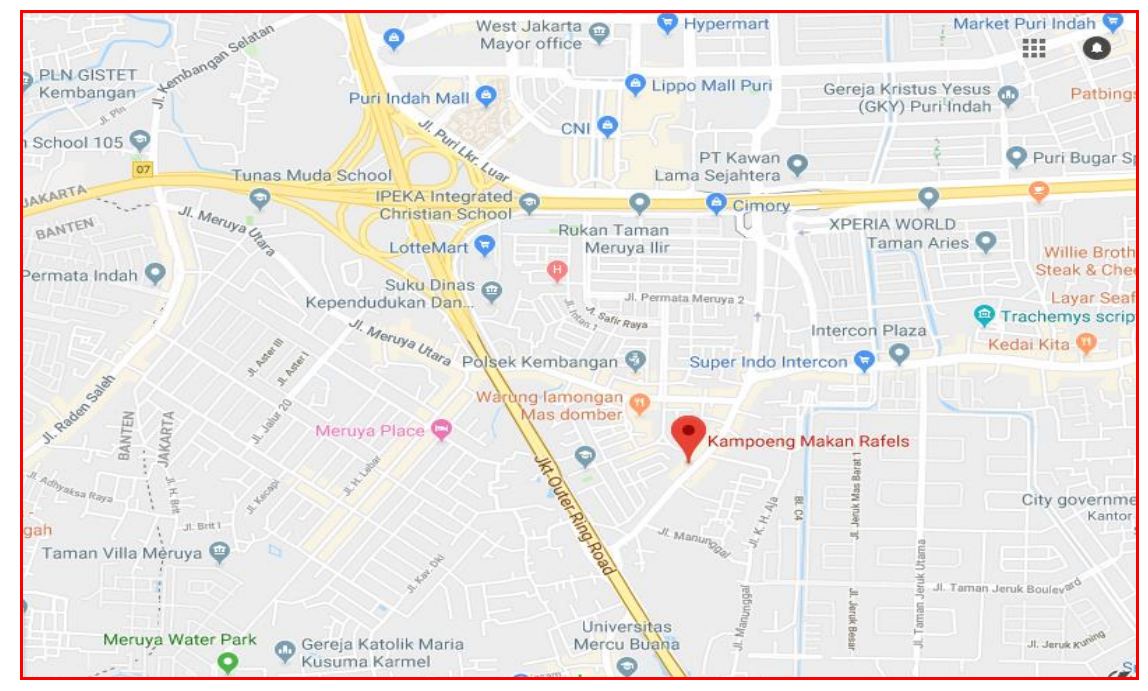

Gambar 1. Lokasi Kampung Makan Rafel's

Sebagaimana peta pada Gambar 1, tampak posisi strategis Kampung Makan Rafel's yang berada 300 meter di sebelah Barat dari Jakarta Outer Ring Road dan 600 meter di sebelah Utara kampus Universitas Mercu Buana. Sejumlah ruang publik di sekitar Kampung Makan Rafel's adalah SD Negeri Meruya Utara 02 Pagi, SMP Negeri 215, Puskesmas Meruya Utara, TK Lazuardi Cordova, Honda Ahass Meruya, serta perkantoran dan pemukiman penduduk. Lahan yang dikelola Kampung Makan Rafel's seluas 500-meter persegi, berkapasitas tujuh tenant kuliner. Sejauh ini para tenant yang bergabung menawarkan jenis kuliner sop dan sate kambing, nasi bebek, nasi bakar, ayam penyet, kebab, dan aneka juice dengan harga berkisar Rp 10.000 - Rp 40.000 per porsi.

Gambar 2 menunjukkan bagaimana Suasana di Kampung Makan Rafel's pada malam hari. Proses bisnis pada Pusat Jajan Serba Ada (Pujasera) dijalankan dengan cara mencari beragam penyedia dan penjual kuliner (tenant) agar dapat memberikan beragam preferensi kepada pelanggan dalam satu lokasi terpadu dan menghasilkan keuntungan untuk pengelola. Pengelola mencari tenant yang bersedia bergabung dengan menawarkan kesiapan tempat makan serta fasilitas penunjang listrik dan air bersih. Jika sejumlah tenant telah terkumpul maka berjalanlah proses bisnis Pujasera. Secara sederhana, biasanya pelanggan memesan sendiri makanan dan/atau minuman pada tenant yang diminati, membayar langsung pada tenant tersebut, selanjutnya tenant akan mengantarkan makanan kepada pelanggan. Pada pujasera yang dikelola secara lebih profesional, pengelola menyediakan kasir terpadu untuk seluruh tenant sehingga omzet masing-masing tenant dapat di rekapitulasi oleh pengelola (Tedjowidjojo, 2016).

Berdasarkan permasalahan dan analisis situasi tersebut maka program pengabdian kepada masyarakat ini ditujukan untuk meningkatkan literasi keuangan bagi tenant Kampung Makan Rafel's. Urgensi pelaksanaan program ini adalah untuk meningkatkan literasi keuangan sehingga para tenant dapat mengenali sumber pembiayaan yang terpercaya, lebih memahami pengelolaan keuangan, dan dapat memilih alokasi investasi dari hasil 
penjualannya. Berbekal tingkat literasi keuangan yang lebih tinggi, diharapkan para tenant dapat mengatasi kendala finansial yang dialaminya dan bisnisnya dapat bertahan secara berkesinambungan.
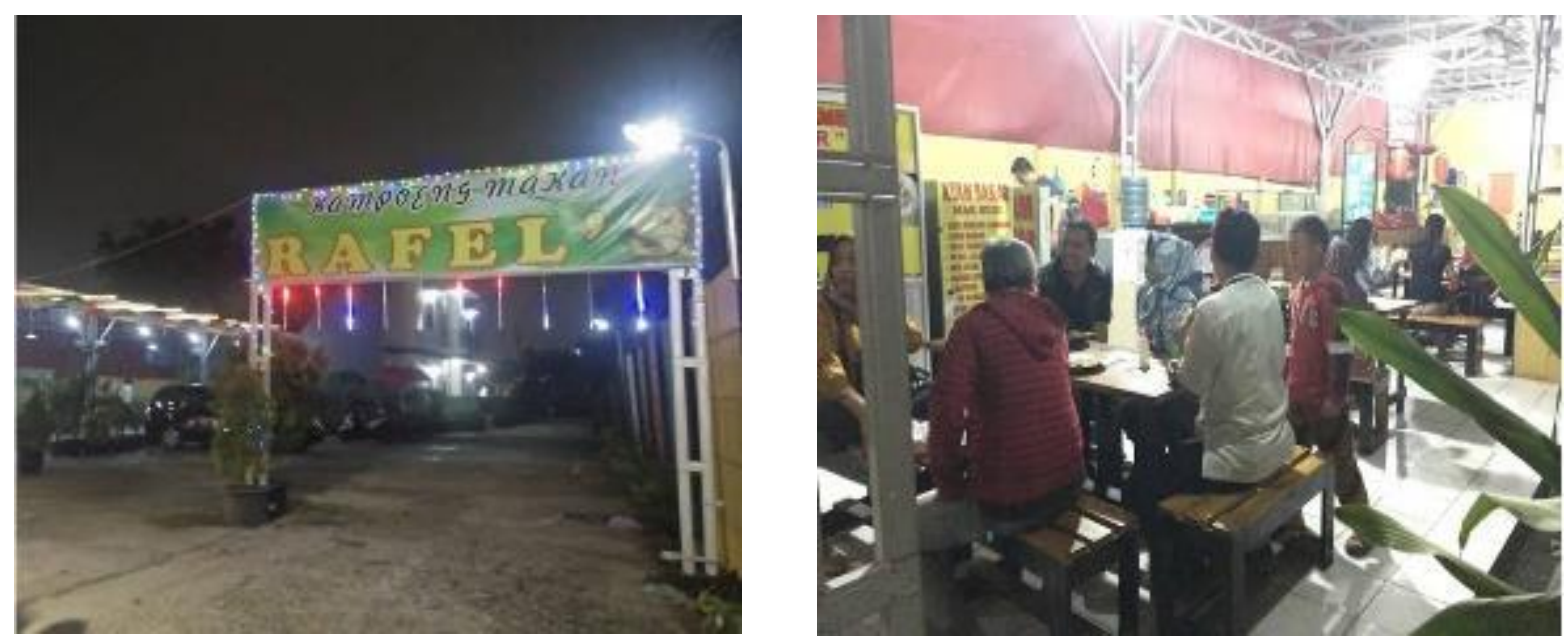

Gambar 2. Suasana di Kampung Makan Rafel's

\section{Materials and Methods}

Kegiatan Pengabdian Kepada Masyarakat ini ditujukan untuk meningkatkan literasi keuangan bagi para tenant dan pengelola Kampung Makan Rafel's. Hal ini akan ditempuh dengan cara melakukan investigasi teknis selama beberapa hari, mewawancarai para tenant dan pengelola mengenai kendala teknis operasional, dan melakukan identifikasi permasalahan secara lebih mendalam. Selanjutnya dilakukan koordinasi untuk menyepakati waktu pertemuan dengan keseluruhan tenant dan pengelola Kampung Makan Rafel's. Dalam pertemuan tersebut, akan dilakukan edukasi mengenai literasi keuangan dan urgensinya bagi eksistensi bisnisnya.

Program Kegiatan Pengabdian Kepada Masyarakat ini terbagi atas tiga tahap, yakni tahap persiapan, tahap pendampingan, serta tahap monitoring dan evaluasi (Paranita et al., 2019). Tahap persiapan terdiri dari tiga kegiatan, yaitu: identifikasi permasalahan yang dihadapi tenant dan pengelola Kampung Makan Rafel's, koordinasi tim pelaksana yang terdiri dari dosen dan satu orang tenaga pendukung, persiapan materi pendampingan, dan peralatan pendukung, koordinasi dengan mitra yaitu para tenant dan pengelola Kampung Makan Rafel's.

Tahap pendampingan terdiri dari tiga kegiatan, yaitu: menyampaikan sosialisasi Literasi Keuangan disertai diskusi, tanya jawab, serta menampung kendala-kendala yang dihadapi para tenant dan pengelola Kampung Makan Rafel's, membagikan buku kas sederhana, dilanjutkan menjelaskan manfaat dan tata cara pengisian buku kas sebagai sarana awal dalam pengelolaan keuangan para tenant dan pengelola Kampung Makan Rafel's, pendampingan penerapan Literasi Keuangan dan praktik penggunaan buku kas, dilaksanakan oleh tim dan tenaga pendukung, dengan cara visitasi ke masing-masing lapak tenant disertai dengan diskusi.

Tahap monitoring dan evaluasi meliputi dua kegiatan yaitu: visitasi ke masing-masing lapak tenant untuk memonitor tingkat pemahaman literasi keuangan dan pengelolaan keuangannya, konsultasi pemahaman literasi keuangan dan pengelolaan keuangan para tenant dan pengelola Kampung Makan Rafel's, solusi atas sejumlah permasalahan yang mereka hadapi. 
Adapun partisipasi para tenant dan pengelola Kampung Makan Rafel's meliputi sejumlah kegiatan berikut: mengemukakan fenomena dan permasalahan manajerial yang dihadapi, mengikuti edukasi tentang literasi keuangan, dan menjalankan program pendampingan dalam upaya peningkatan literasi keuangan.

\section{Results and Discussion}

Kunjungan pertama dalam kegiatan Pengabdian Kepada Masyarakat di Kampung Makan Rafel's mencakup aktivitas identifikasi masalah, koordinasi dengan tenaga pendukung, serta koordinasi dengan tenant dan pengelola Kampung Makan Rafel's. Tahap persiapan telah dimulai sebelum kunjungan pertama dengan cara koordinasi dengan tenaga pendukung serta koordinasi dengan pengelola Kampung Makan Rafel's.

Selanjutnya tahap pendampingan dilakukan dengan menyampaikan sosialisasi literasi keuangan yang diikuti dengan diskusi dan tanya jawab. Dalam kesempatan tersebut juga ditampung kendala-kendala yang dikemukakan para tenant dan pengelola Kampung Makan Rafel's. Tahap ini berjalan sangat intensif dalam suasana penuh kekeluargaan sehingga pembahasan dapat berlangsung lebih cair dan mendalam. Edukasi literasi keuangan disampaikan dengan tujuan para tenant dan pengelola Kampung Makan Rafel's: 1) Mampu memanfaatkan produk jasa keuangan sesuai dengan kebutuhannya. Jasa keuangan perbankan dan non perbankan belum cukup familiar bagi para tenant dan pengelola Kampung Makan Rafel's, sehingga dijelaskan manfaat menabung pada perbankan, pemilihan produk perbankan termasuk pembiayaan, dan pemahaman fitur produk perbankan yang sesuai dengan kebutuhan mereka. 2) Mampu melakukan perencanaan keuangan dengan lebih baik. Tim mengarahkan agar para tenant dan pengelola Kampung Makan Rafel's menyusun perencanaan keuangan sederhana terkait pencatatan pemasukan dan pengeluaran operasional, menyisihkan hasil penjualan untuk membayar uang sewa lapak, dan menargetkan untuk melengkapi peralatan produksi yang lebih memadai. 3) Terhindar dari aktivitas investasi pada instrumen keuangan yang menjerumuskan. Investasi pada instrumen keuangan yang aman hanyalah pada penyedia jasa keuangan yang terdaftar di Otoritas Jasa Keuangan. Selain itu juga diinformasikan bahwa investasi pada instrumen keuangan yang menjanjikan keuntungan sangat tinggi dapat dipastikan merupakan penipuan.

Tahap tersebut dilanjutkan dengan pembagian buku kas sederhana dan penjelasan cara pengisiannya sebagai upaya mendasar pengelolaan keuangan. Tim menjelaskan pencatatan keuangan operasional baik pencatatan kas masuk dari penjualan makanan langsung di Kampung Makan Rafel's maupun kas masuk dari penjualan berbasis aplikasi online. Kas masuk tunai dialokasikan untuk pembelian bahan baku, sedangkan kas masuk ke rekening dari aplikasi online diarahkan untuk disisihkan sebagai tabungan di rekening yang tersebut. Adapun pencatatan kas keluar meliputi pembelian bahan baku dan pembayaran sewa lapak. Satu demi satu tenant diberikan pemahaman tentang pengisian masing-masing pemasukan di kolom debet, pengeluaran di kolom kredit, dan cara menghitung saldonya.

Pemahaman literasi keuangan para tenant di Kampung Makan Rafel's terkait produk jasa keuangan masih sangat minim. Terkait jasa keuangan jenis penyimpanan, semua tenant dan pengelola Kampung Makan Rafel's hanya memiliki satu rekening tabungan pada bank rekanan aplikasi online yang diikutinya. Pemasukan penjualan yang diterima biasanya langsung dibelanjakan untuk pembelian bahan baku dan kebutuhannya sehari-hari. Adapun terkait jasa keuangan jenis pembiayaan, belum ada tenant yang pernah memanfaatkan pembiayaan dari perbankan. Mereka cenderung memilih pinjaman berbasis aplikasi online atau bahkan rentenir yang dinilai lebih praktis, tanpa memahami konsekuensinya dan menanggung biaya bunga yang sangat tinggi. Kondisi ini tak lepas dari latar belakang pendidikan para tenant dari pendidikan dasar dan menengah sehingga berimbas pada rendahnya literasi keuangan, sebagaimana temuan Purwidianti \& Tubastuvi (2019), Amalia 
\& Rahmawati (2019), dan Lantara \& Kartini (2015). Untuk itu, sejalan dengan rekomendasi sejumlah program pengabdian masyarakat dan studi sebelumnya, tim pengabdian kepada masyarakat telah melakukan edukasi literasi keuangan secara intensif agar para tenant semakin memahami produk jasa keuangan dan dapat memilah dengan tepat sumber pembiayaan yang terpercaya dan aman (Sabilla \& Wijayangka, 2019; Pramestiningrum \& Iramani, 2020; Panggabean et al., 2018).

Pemahaman literasi keuangan para tenant di Kampung Makan Rafel's terkait perencanaan keuangan juga masih sangat minim. Selama ini mereka hanya berpikir pemasukan hari ini untuk membiayai pengeluaran esok hari. Selain itu mereka juga belum memisahkan arus kas keluar masuk dari usahanya dengan arus kas keluar masuk dalam rumah tangganya. Hal ini rentan dalam mempertahankan kesinambungan usahanya mereka, seperti fenomena mayoritas UMKM di berbagai daerah (Sudana et al., 2017; Suryani \& Ramadhan, 2017; Tedjowidjojo, 2016; Anggraeni, 2016; Jumhur, 2015). Berkenaan dengan hal tersebut, tim pengabdian kepada masyarakat ini melakukan edukasi pemanfaatan buku kas sebagai sarana pengelolaan keuangan sederhana. Buku kas yang diisi setiap hari akan dapat memonitor margin yang diperoleh setiap hari, selain itu juga otomatis mencatat arus kas usaha yang terpisah dari arus kas rumah tangga. Dengan upaya tersebut diharapkan para tenant dapat mempertahankan kelangsungan usahanya, meneladani sejumlah UMKM yang semakin eksis setelah meningkat literasi keuangannya (Puspitaningtyas, 2017; Paranita et al., 2019; Rahayu \& Musdholifah, 2017; Purwidianti \& Tubastuvi, 2019; Eniola \& Entebang, 2015).

Selanjutnya pemahaman literasi keuangan para tenant di Kampung Makan Rafel's terkait investasi pada instrumen keuangan juga sangat minim. Tidak ada tenant yang mengalokasikan labanya untuk investasi karena kendala keterbatasan pendapatannya. Demikian juga perencanaan mengenai investasi, sama sekali belum masuk dalam pemikiran saat ini. Konsep investasi yang dipahami para tenant dan pengelola Kampung Makan Rafel's terbatas pada penambahan peralatan dapur, reparasi kompor, dan penggantian instalasi listrik. Para tenant dan pengelola Kampung Makan Rafel's berpotensi menjadi mangsa empuk pihak-pihak tak bertanggung jawab yang menawarkan investasi dengan penghasilan yang menggiurkan. Fenomena ini ditemui juga pada sejumlah penelitian dan program pengabdian kepada masyarakat di sektor informal (Jumhur, 2015) (Hafifah, 2019) (Aribawa, 2016) (Nohong et al., 2019) (Susdiani, 2017). Mengatasi hal tersebut, tim pengabdian kepada masyarakat ini mengedukasi para tenant bahwa jenis-jenis investasi aman hanyalah investasi produk perbankan dan produk lembaga keuangan yang terdaftar pada Otoritas Jasa Keuangan. Selain itu juga ditekankan kembali kepada para tenant agar tidak mudah tergiur investasi yang menjanjikan keuntungan luar biasa. Tingginya literasi keuangan akan sebanding dengan tingkat kematangan berpikir dan pengambilan keputusan dalam pemilihan produk investasi (Putra et al., 2016; Susdiani, 2017; Mabula \& Ping, 2018; Mashizha et al., 2019; dan Agyapong \& Attram, 2019). Gambar 3 mengilustrasikan kegiatan pendampingan peningkatan literasi keuangan di Kampung Makan Rafel's.

Kunjungan kedua yang dilakukan tim pengabdian kepada masyarakat di Kampung Makan Rafel's merupakan tahap monitoring dan evaluasi. Tiga bulan setelah kunjungan pertama, tim pengabdian kepada masyarakat kembali memantau pengelolaan keuangan para tenant dan pengelola Kampung Makan Rafel's dengan cara memonitor pengisian buku kas. Berdasarkan pemantauan, semua tenant telah mengisi buku kas dengan tertib. Pengisian buku kas dengan tertib menuntun mereka untuk mengetahui biaya tetap dan biaya variabel setiap bulan, dan juga dapat menghitung margin keuntungan bersih yang diperoleh. Selain itu juga diingatkan kembali tentang pentingnya pemisahan pencatatan keuangan operasional usaha dengan keuangan operasional rumah tangganya. Dengan demikian diprediksikan bahwa proses bisnis di Kampung Makan Rafel's akan mampu bertahan, sejalan dengan saran tindak 
lanjut dalam program inovasi bisnis pujasera di Surabaya (Tedjowidjojo, 2016), upaya pertumbuhan usaha UMKM binaan PPKM di Rancaekek dan Ciluenyi (Sabilla \& Wijayangka, 2019), serta dapat meningkatkan perilaku keuangannya sebagaimana UMKM di Purwokerto Selatan (Purwidianti \& Tubastuvi, 2019) dan UMKM di Jawa Timur (Pramestiningrum \& Iramani, 2020).

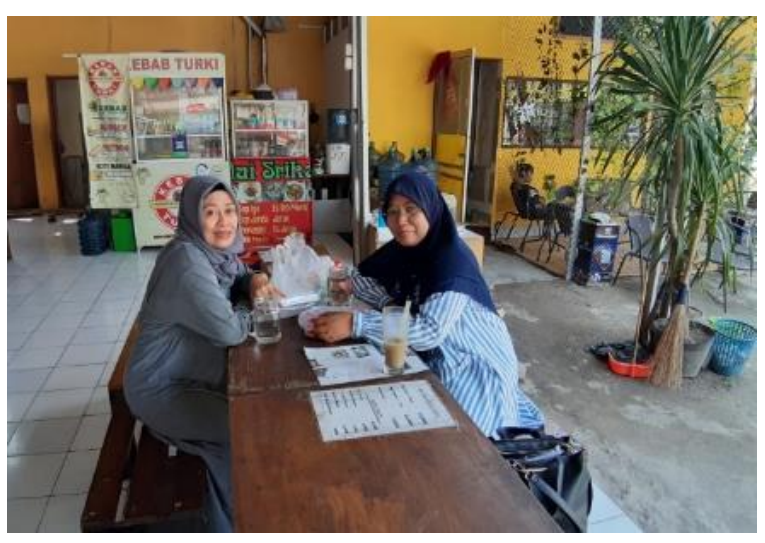

Wawancara dengan pengelola

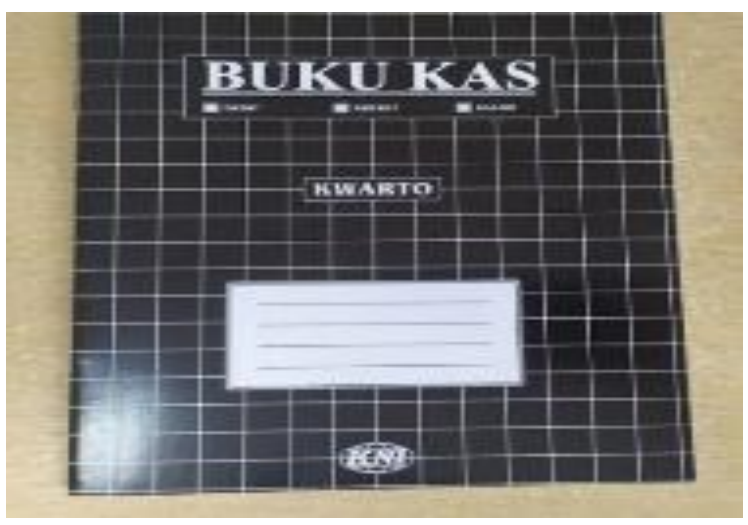

Buku kas yang disosialisasikan

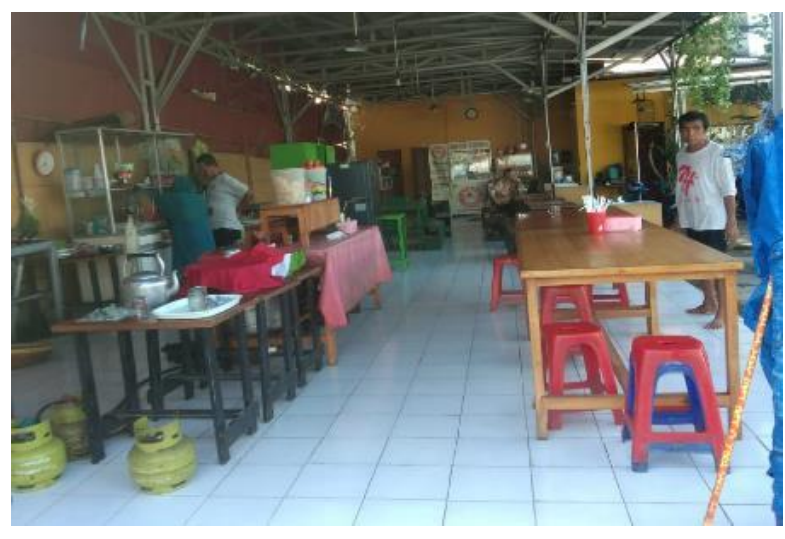

Aktifitas beberapa tenant

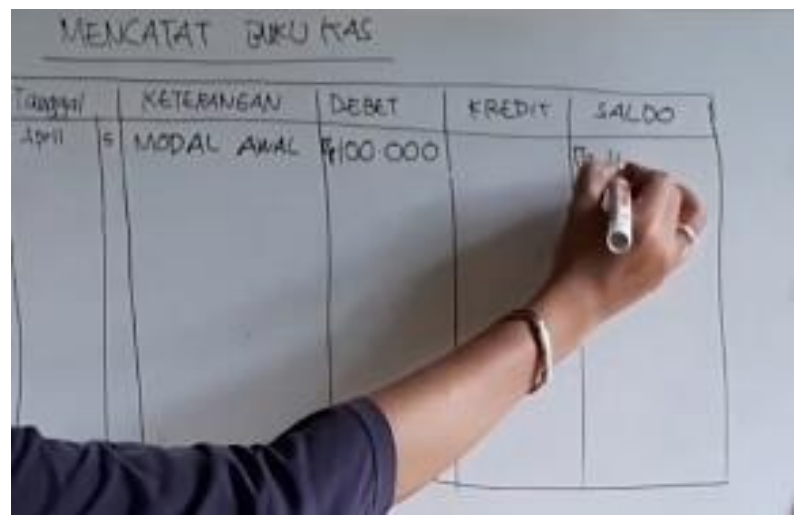

Pendampingan pengisian buku kas

Gambar 3. Pendampingan Literasi Keuangan

Setelah mengapresiasi kemajuan tersebut, tim pengabdian kepada masyarakat mengedukasi agar para tenant dan pengelola Kampung Makan Rafel's berusaha menyisihkan sebagian keuntungannya untuk menabung di bank. Tenant dan pengelola Kampung Makan Rafel's yang sudah familiar dengan perbankan diarahkan kelak pada saat memerlukan pembiayaan untuk pengembangan usahanya juga akan memanfaatkan jasa pembiayaan perbankan, tidak lagi menggunakan jasa rentenir atau beragam jasa pinjaman berbasis aplikasi online yang tidak bertanggung jawab. Hal tersebut sejalan dengan rekomendasi program pendampingan UMKM terjerat rentenir di Nganjuk (Amalia \& Rahmawati, 2019), serta upaya mempertahankan kelangsungan bisnis (Panggabean et al., 2018; Anggraeni, 2016; dan Rahayu \& Musdholifah, 2017).

Tim pengabdian kepada masyarakat berupaya menggali permasalahan yang masih dihadapi para tenant dan pengelola Kampung Makan Rafel's. Namun rendahnya tingkat literasi keuangan yang dilandasi rendahnya latar belakang pendidikan, rendahnya akses ke penyedia jasa keuangan, serta rendahnya tingkat pendapatan para tenant menyebabkan proses pemecahan masalah belum tuntas dan masih membutuhkan pendampingan. Selanjutnya 
program ditutup dengan evaluasi simultan bersama seluruh tenant dan pengelola Kampung Makan Rafel's. Secara umum, seluruh pihak merasa terbantu dengan pengetahuan dan keterampilan baru terkait literasi keuangan, berupaya dapat diimplementasikan dalam pengelolaan keuangan di Kampung Makan Rafel's, dan berharap masih ada program pendampingan selanjutnya untuk mendukung eksistensi pengelolaan Kampung Makan Rafel's secara profesional.

\section{Conclusion}

Kegiatan pengabdian kepada masyarakat dalam peningkatan literasi keuangan pada tenant dan pengelola Kampung Makan Rafel's diselenggarakan dalam tahap persiapan, pendampingan, serta monitoring dan evaluasi. Setelah program tersebut terlaksana, literasi keuangan tenant dan pengelola Kampung Makan Rafel's cukup meningkat untuk menunjang operasional mereka dan memastikan mereka teredukasi secara memadai dan memahami produk dan jasa keuangan sesuai kebutuhan mereka. Tenant dan pengelola Kampung Makan Rafel's mulai sadar pentingnya menabung serta paham fungsi dan fitur rekening tabungan. Selain itu, mereka juga telah mengerti sumber pembiayaan terpercaya adalah dari perbankan dan lembaga keuangan yang terdaftar di Otoritas Jasa Keuangan. Perencanaan keuangan yang diawali dengan pencatatan arus kas masuk dan kas keluar dalam buku kas diharapkan akan berlangsung kontinyu. Kesadaran bahwa investasi yang terpercaya hanyalah produk investasi perbankan dan lembaga keuangan terdaftar di Otoritas Jasa Keuangan, sehingga tidak mudah tertipu penawaran jasa dan investasi yang menggiurkan.

Tenant dan pengelola Kampung Makan Rafel's masih membutuhkan pendampingan untuk meningkatkan literasi keuangan dan meningkatkan perilaku keuangannya. Program pendampingan lanjutan diharapkan dapat mempertahankan pengetahuan dan keterampilan tenant dalam menggunakan buku kas. Penerapan buku kas secara tertib diarahkan untuk pencatatan operasional keuangan secara detil, selanjutnya menyisihkan tabungannya pada bank setempat, serta mengalokasikan untuk investasi pada intrumen perbankan atau lembaga keuangan terpercaya. Para tenant juga masih perlu dipantau untuk memisahkan anggaran pengelolaan usahanya dari anggaran rumah tangganya. Dengan demikian, di masa mendatang diharapkan tenant dapat mengelola keuangan usahanya secara layak dan memadai, serta dapat terwujud inklusi keuangan di Kampung Makan Rafel's.

\section{Acknowledge}

Ucapan terima kasih kami disampaikan kepada Lembaga Penelitian dan Pengabdian Kepada Masyarakat Universitas Sahid yang mendanai kegiatan pengabdian kepada masyarakat di Kampung Makan Rafel's dalam Hibah Pengabdian Kepada Masyarakat tahun 2019 Batch 7

\section{References}

Agyapong, D., \& Attram, A. B. (2019). Effect of Owner-Manager's Financial Literacy on the Performance of SMEs in the Cape Coast Metropolis in Ghana. Journal of Global Entrepreneurship Research, 9(1), 1-13. https://doi.org/10.1186/s40497-019-0191-1

Amalia, A. F., \& Rahmawati, L. (2019). Pendampingan Manajemen Keuangan Melalui Program Literasi Keuangan Kepada Komunitas Usaha Mikro Kecil dan Menengah (UMKM) yang Terjerat Rentenir di Kabupaten Nganjuk. Engagement: Jurnal Pengabdian Kepada Masyarakat, $\quad 3(1), \quad 113-126$. https://doi.org/10.29062/engagement.v3i1.55

Anggraeni. (2016). Pengaruh Tingkat Literasi Keuangan Pemilik Usaha terhadap Pengelolaan Keuangan : Studi Kasus UMKM Depok. Jurnal Vokasi Indonesia, 4(1), 43-50. 
Aribawa, D. (2016). Pengaruh literasi keuangan terhadap kinerja dan keberlangsungan UMKM di Jawa Tengah. Jurnal Siasat Bisnis, 20(1), 1-13. https://doi.org/10.20885/jsb.vol20.iss1.art1

Eniola, A. A., \& Entebang, H. (2015). Financial Literacy and SME Firm Performance. International Journal of Research Studies in Management, 5(1), 31-43. https://doi.org/10.5861/ijrsm.2015.1304

Hafifah, A. (2019). Literasi Keuangan Pada Pelaku Usaha Mikro Kecil dan Menengah di Kecamatan Ambulu Kabupaten Jember. Prosiding Seminar Nasional Dan Call for Paper-2019, http://jurnal.unmuhjember.ac.id/index.php/sncp/article/view/2023 259-271.

Jumhur. (2015). Model Pengembangan Pedagang Kaki Lima (PKL) Kuliner di Kota Singkawang. Jurnal Ekonomi Bisnis Dan Kewirausahaan, 4(1), 125-139. https://doi.org/10.26418/jebik.v4i1.11464

Lantara, I. W. N., \& Kartini, N. K. R. (2015). Financial Literacy among University Students : Empirical Evidence from Indonesia. In Journal of Indonesian Economy and Business (Vol. 30, Issue 3).

Mabula, J. B., \& Ping, H. D. (2018). Financial Literacy of SME Managers' on Access to Finance and Performance: The Mediating Role of Financial Service Utilization. International Journal of Advanced Computer Science and Applications, 9(9), 32-41. https://doi.org/10.14569/ijacsa.2018.090905

Mashizha, M., Sibanda, M., \& Maumbe, B. (2019). Financial Literacy among Small and Medium Enterprises in Zimbabwe. The Southern African Journal of Entrepreneurship and Small Business Management, 11(1), 1-10. https://doi.org/10.4102/sajesbm.v11i1.241

Masiyamoorthy, P., Vidhya, K., \& Rajendhiran, N. (2017). Financial Literacy and Small Scale Industries Firm Performance in India. International Journal of Research in Social Sciences, 2249-2496.

Mukhibat. (2020). Konstruksi Mutu Pendidikan melalui Literasi Keuangan pada Pendidikan Anak Usia Dini di Magetan. Jurnal Obsesi : Jurnal Pendidikan Anak Usia Dini, 4(2), 620. https://doi.org/10.31004/obsesi.v4i2.412

Nadya, \& Karina, N. M. (2017). Analisis Tingkat Literasi Keuangan Pada Dosen Universitas Telkom Tahun 2016. Jurnal Ekonomi, Bisnis \& Entrepreneurship, 11(2), 75-88. http://jurnal.stiepas.ac.id/index.php/jebe/article/download/199/261

Nohong, M., Ali, M., Sohilauw, M., Sobarsyah, M., \& Munir, A. (2019). Financial Literacy and Competitive Advantage: SME Strategy in Reducing Business Risk. Revista Espacios, 40, 12-16.

Panggabean, F. Y., Dalimunthe, M. B., Aprinawati, A., \& Napitupulu, B. (2018). Analisis Literasi Keuangan terhadap Keberlangsungan Usaha Kuliner Kota Medan. Jurnal Manajemen Dan Keuangan, 7(2), 139-147. https://doi.org/10.33059/jmk.v7i2.872

Paranita, E. S., Levyda, L., \& Giyatmi, G. (2019). Peningkatan Literasi Keuangan Pemilik Homestay Di Pulau Harapan Kepulauan Seribu. Wasana Nyata, 3(2), 157-167.

Pramestiningrum, D. R., \& Iramani, I. (2020). Pengaruh Literasi Keuangan, Financial Capital, Kebijakan Pemerintah terhadap Kinerja Usaha pada Usaha Kecil dan Menengah di Jawa Timur. Journal of Business and Banking, 9(2), 279. 
https://doi.org/10.14414/jbb.v9i2.1750

Purwidianti, W., \& Tubastuvi, N. (2019). The Effect of Financial Literacy and Financial Experience on SME Financial Behavior in Indonesia. Jurnal Dinamika Manajemen, 10(1), 40-45. https://doi.org/10.15294/jdm.v10i1.16937

Puspitaningtyas, Z. (2017). Manfaat Literasi Keuangan Bagi Business Sustainability. Seminar Nasional Kewirausahaan Dan Inovasi Bisnis VII, ISSN: 2089-1040, 254-262.

Putra, I. P. S., Ananingtiyas, H., Sari, D. R., Dewi, A. S., \& Silvy, M. (2016). Pengaruh Tingkat Literasi Keuangan, Experienced Regret, dan Risk Tolerance pada Pemilihan Jenis Investasi. Journal of Business and Banking, 5(2), 271-282. http://dx.doi.org/10.14414/jbb.v5i2.707

Rahayu, A. Y., \& Musdholifah. (2017). Pengaruh Literasi Keuangan terhadap Kinerja dan Keberlanjutan UMKM di Kota Surabaya. Jurnal Ilmu Manajemen, 5(3), 1-7. https://jurnalmahasiswa.unesa.ac.id/index.php/jim/article/view/20256

Ripain, N., Amirul, S. M., \& Mail, R. (2017). Financial Literacy and SMEs' Potential Entrepreneurs: The Case of Malaysia. Journal of Administrative and Business Studies, 3(2), 60-68. https://doi.org/10.20474/jabs-3.2.1

Sabilla, S. O., \& Wijayangka, C. (2019). Pengaruh Literasi Keuangan terhadap Pertumbuhan Usaha pada UMKM. Almana: Jurnal Manajemen Dan Bisnis, 3(1), 145-152. https://doi.org/10.36555/almana.v3i1.457

Sudana, M., Putra, I. G. S. A., \& Nyoman, P. (2017). Pemberdayaan Masyarakat Desa dengan Usaha Kuliner Tradisional pada Kelompok Boga Ganesha Kabupaten Buleleng. Jurnal Agribisnis Dan Agrowisata, 6(3), 387-396. https://doi.org/10.24843/jaa.2017.v06.i03.p07

Suryani, S., \& Ramadhan, S. (2017). Analisis Literasi Keuangan pada Pelaku Usaha Mikro di Kota Pekanbaru. Journal of Economic, Business and Accounting, 4(1), 9-15. https://doi.org/10.31539/costing.v1i1.67

Susdiani, L. (2017). Pengaruh Financial Literacy dan Financial Experience Terhadap Perilaku Perencanaan Investasi PNS Di Kota Padang. Jurnal Pembangunan Nagari, 2(1), 6174.

Tedjowidjojo, A. T. L. (2016). Inovasi Proses Bisnis Pada Pujasera Ndokee Di Surabaya. Agora, 5(1).

Ye, J., \& Kulathunga, K. M. M. C. B. (2019). How Does Financial Literacy Promote Sustainability in SMEs? A Developing Country Perspective. Sustainability, 11(10), 121. https://doi.org/10.3390/su11102990 